\title{
A new variety of Brachystelma maculatum (Apocynaceae) from Andhra Pradesh, India
}

\author{
Nagendra C. ${ }^{1}$, Nagaraju V. ${ }^{2}$, Madhusudhana Reddy A. ${ }^{1}$ \& K. Prasad ${ }^{3 *}$ \\ ${ }^{1}$ Department of Botany, Yogi Vemana University, Kadapa, Andhra Pradesh - 516 005, India \\ 2Department of Botany, Sri Venkateswara University, Tirupati, Andhra Pradesh - 517 502, India \\ ${ }^{3}$ Andhra Pradesh State Biodiversity Board, Raintree Park, Opp. Nagarjuna University, Guntur, Andhra Pradesh - 522 508, India \\ *E-mail: prasad.orchids@gmail.com
}

\begin{abstract}
A new variety of Brachystelma maculatum Hook.f. is described from Anantapuram district of Andhra Pradesh, India. A detailed description, photographs and conservation status are provided for the new variety.
\end{abstract}

Keywords: Anantapuram district, Ceropegieae, Conservation assessment, Nigidi Reserve Forest.

\section{Introduction}

Brachystelma R.Br. is the second largest genus of tribe Ceropegieae (Apocynaceae) with about 160 species which are distributed mainly in the Old World tropics, particularly in Sub-Saharan Africa, India, Sri Lanka, South East Asia and Northern Australia (Venu \& Prasad, 2015). So far 34 species are reported from India and all of them are known to be confined to Indian political boundaries (Prasad \& Venu, 2020). The genus Brachystelma has been traditionally distinguished from the morphologically similar Ceropegia L. by its completely open flowers (non-tubular) against a tubular corolla in the latter. During recent floristic field surveys for bulbous plants in the southern Eastern Ghats of Andhra Pradesh, we located a population of Brachystelma, which was found growing in grassy patches in dry deciduous forests of the Nigidi Reserve Forest in Anantapuram district. After critical examination of the collected

Received: 12.11.2020; Revised \& Accepted: 22.01.2021

Published Online: 31.03 .2021 specimens and perusal of the relevant literature, it was found to be represents a variant of Brachystelma maculatum Hook.f., which was recently located near the Sikharam area in the Nalamalla hills of Andhra Pradesh (Prasad \& Venu, 2018). The present taxon exhibits a few differences in flower bud shape, size of corolla lobes and inter-staminal corona. Therefore, it is recognized as a new variety of Brachystelma maculatum. A key to the varieties of Brachystelma maculatum is also provided.

\section{Taxonomic treatment}

Brachystelma maculatum Hook.f. var. breviflorum Nagendra, V.Nagaraju, A.M.Reddy \& K.Prasad, var. nov.

Figs. $1 \& 2$

Brachystelma maculatum var. breviflorum is similar to the type variety maculatum, but differs in having ovate flower buds ( $v$ s. lanceolate), narrowly ovate or ovate-triangular, 4.5-5 mm long, straight corolla lobes ( $v s$. broadly ovate at base then narrowed towards apex, more than $10 \mathrm{~mm}$ long, kneeled above down the middle) and bifid interstaminal corona ( $v s$. entire).

Type: INDIA, Andhra Pradesh, Anantapuram district, Nigidi Reserve Forest, 24.08.2019, C. Nagendra \& V. Nagaraju 5170 (holo BSID!; iso Yogi Vemana Herbarium!, Yogi Vemana University, Kadapa!).

Perennial herbs, 40-60 cm high. Tubers with different shapes, generally fusiform, 3-5 $\times 1-2 \mathrm{~cm}$, rarely globose, c. $3 \times 3 \mathrm{~cm}$. Stems slender, terete, unbranched, glabrous; internodes $c .7 .5 \mathrm{~cm}$ long. Leaves sessile, filiform, $4-11 \times 0.1 \mathrm{~cm}$, margins 

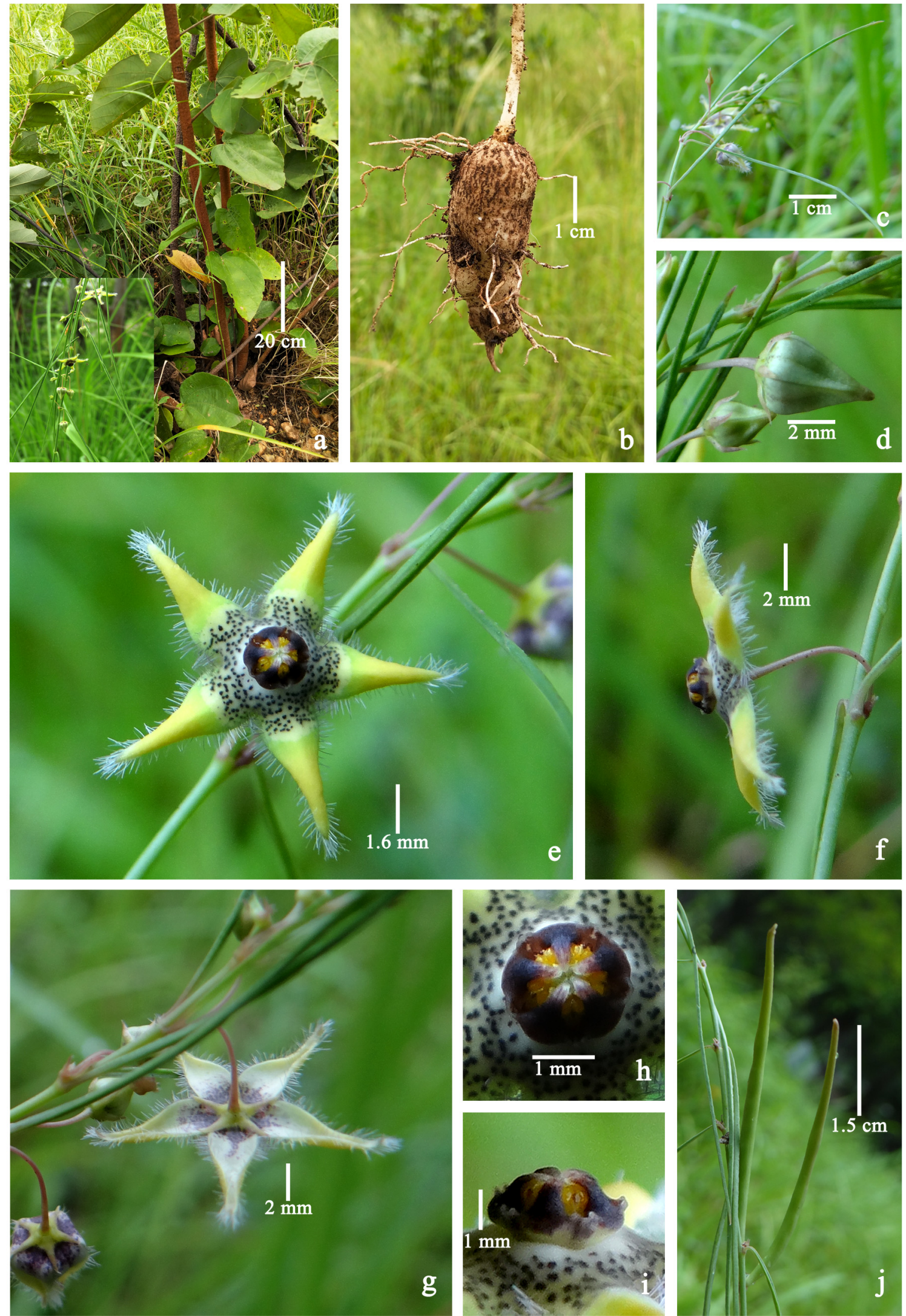

Fig. 1. Brachystelma maculatum Hook.f. var. breviflorum Nagendra, V.Nagaraju, A.M.Reddy \& K.Prasad: a. Habit; b. Tuber; c. Leaf; d. Flower buds; e. Flower-front view; f. Flower-side view; g. Flower-back view; h. Corona-top view; i. Corona-side view; j. Follicles (from C. Nagendra \& V. Nagaraju 5170; photos by C. Nagendra \& V. Nagaraju). 

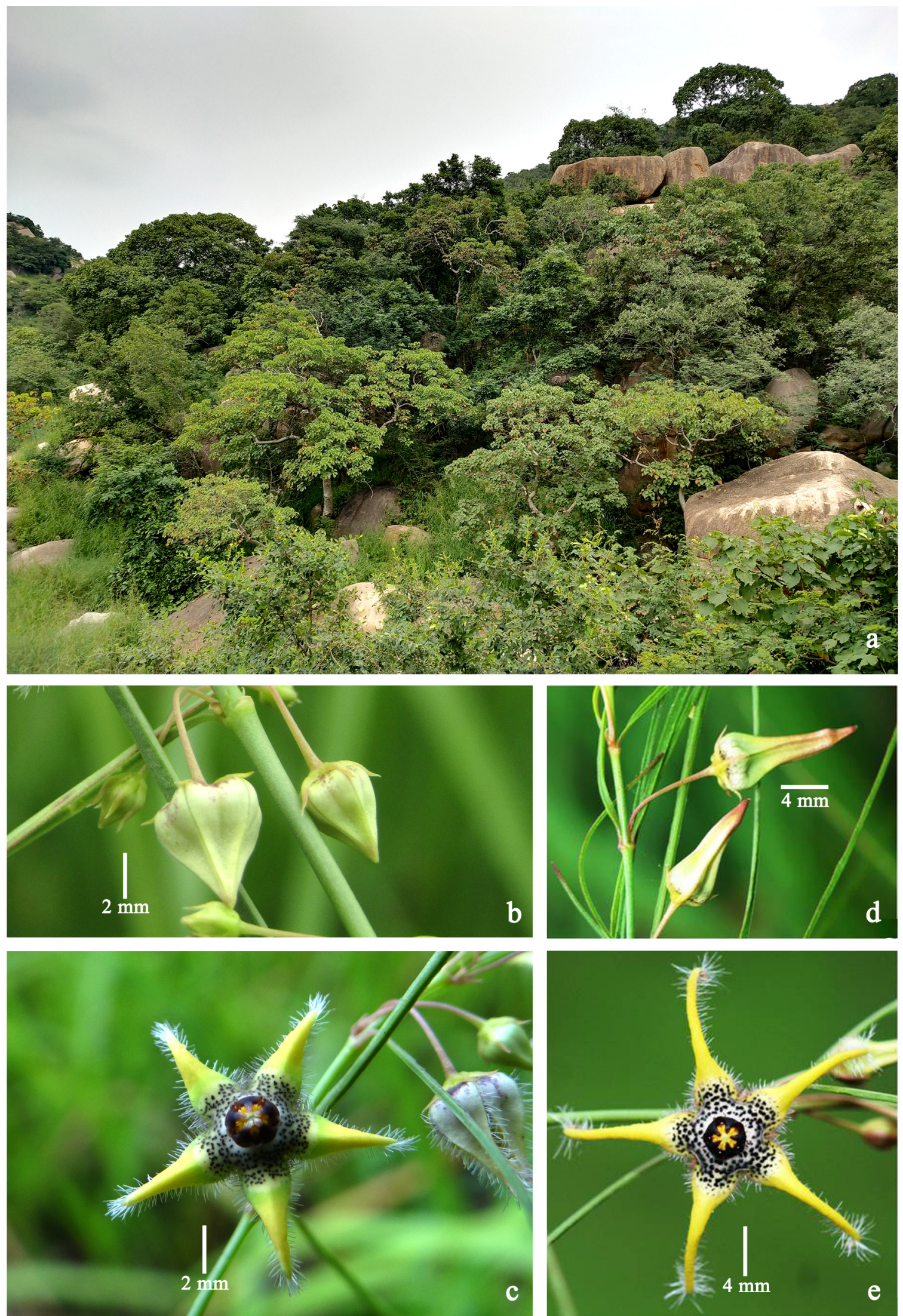

Fig. 2. a-c. Brachystelma maculatum Hook.f. var. breviflorum Nagendra, V.Nagaraju, A.M.Reddy \& K.Prasad: a. Habitat; b. Flower buds; c. Flower; d-e. Brachystelma maculatum Hook.f. var. maculatum: d. Flower buds; e. Flower (photos by K. Prasad). 
ciliate, apex acute, glabrous. Cymes lateral or axillary, sub-sessile or shortly pedunculate, 2-3flowered; pedicels filiform, 5-6 mm long, glabrous; bracts and bracteoles small, subulate, acute at apex, glabrous, persistent; bract 1, $0.6 \mathrm{~mm}$ long; bracteoles 2, $0.4 \mathrm{~mm}$ long. Flower buds ovate in shape; flowers pendulous. Calyx lobes linear, 2-2.2 $1 \mathrm{~mm}$, acute at apex, glabrous, pinkish-green. Corolla rotate, lemon yellow, basal region with paler colour and prominently black mottled; tube short, $0.8-1 \mathrm{~mm}$ long; lobes narrowly ovate or ovate-triangular, 4.5$5 \times 1.9-2 \mathrm{~mm}$, margins revolute and hairy, apex twisted sideways or inward; hairs white, c. $2 \mathrm{~mm}$ long; black mottled ornamentation limited to basal portions of lobes. Corona black, 1.6-2 mm in diam., glabrous; inter-staminal corona 5-angled, cupular, forming continuous ring around gynostegium, lobes bifid; lobules short, triangular; staminal corona lobes broadly triangular at base then narrowing towards apex, $1.2-1.5 \mathrm{~mm}$ long, $0.8 \mathrm{~mm}$ broad at base. Pollinia yellow, ellipsoid. Follicles in pair, divergent, narrowing towards the apex, c. $6 \mathrm{~cm}$ long.

Flowering \& fruiting: Flowering from August to September; fruiting from September to October.

Habitat: In blackish-red soils among grasses in dry deciduous forests, at 500-600 m elevation.

Etymology: This new variety is named with reference to its shorter flowers.

Distribution: The new variety is presently known only from the type locality, Nigidi Reserve Forest, Anantapuram district, Andhra Pradesh.

Conservation status: The new variety, Brachystelma maculatum var. breviflorum, is known only from the type locality, Nigidi Reserve Forest. The population here has less than 50 mature individuals spread in an area of about $1 \mathrm{~km}^{2}$. However, the present habitat is affected by seasonal forest fires, grazing and other anthropogenic factors. The new taxon is assessed here as Data Deficient (DD) since further exploration in the adjacent hill tracts is necessary to ascertain its actual status (IUCN, 2019).

\section{Key to the varieties of Brachystelma maculatum}

1. Corolla lobes more than $10 \mathrm{~mm}$ long, broad at base then narrowed towards apex, kneeled above down the middle; inter-staminal corona entire var. maculatum

1. Corolla lobes $4.5-5 \mathrm{~mm}$ long, narrowly ovate or ovate-triangular, not kneeled above down the middle; inter-staminal corona bifid var. breviflorum

\section{Acknowledgements}

The authors are thankful to Dr. B.M.K. Reddy, Chairman and Dr. D. Nalini Mohan, PCCF (IFS), Member Secretary, Andhra Pradesh State Biodiversity Board (APSBB) for support and also thank the Director, Botanical Survey of India for encouragement. The authors are thankful to Prof. M. Surya Kalavathi, Vice-Chancellor, Yogi Vemana University, Kadapa for her constant support and guidance. The authors gratefully acknowledge the Ministry of Environment Forest and Climate Change (MoEF \&CC) (No.10/16/ 2016-CS/BG. Dated: 31-03-2017) for financial support under the ABG scheme.

\section{Literature Cited}

IUCN 2019. Red List Categories and Criteria: Version 14. Prepared by the Standards and Petitions Committee. Available at: http://www.iucnredlist.org/documents/ RedListGuidelines.pdf

PRASAD K. \& P. VENU 2018. Rediscovery and notes on Brachystelma maculatum (Apocynaceae). Rheedea 28(2): 73-77. https://doi.org/10.22244/rheedea.2018.28.2.14

PRASAD K. \& P. VENU 2020. A taxonomic revision of the genus Brachystelma R.Br. in India. Bishen Singh Mahendra Pal Singh, Dehra Dun.

VENU P. \& K. PRASAD 2015. The existential crisis in Indian Brachystelma (Apocynaceae). Current Science 109(4): 680-682. 